\title{
Compensatory Renal Growth in the Mouse. II. The Effect of Growth Hormone Deficiency
}

\author{
J. M. HUTSON, ${ }^{(58)}$ J. E. GRAYSTONE, K. EGAMI, R. FOWLER, AND D. B. CHEEK \\ Department of Surgery and Research Foundation, Royal Children's Hospital, Melbourne, Australia
}

\begin{abstract}
Summary
Allometry was used to study the effect of growth hormone (GH) deficiency on compensatory renal growth (CRG) in a dwarf mouse strain (Little). Nucleic acid and protein estimations were used to assess changes in cellular hyperplasia and hypertrophy. Nephrectomy was performed at 5,15 , or 35 days of age with removal of the renoprival kidney 15 days later. Controls underwent sham nephrectomies at 35 days of age. The allometric growth of the normal kidney in the homozygote dwarf (lit/lit) between 8 and 50 days of age was closely related to that of the normal heterozygote (lit/ $+)$. A regression line for the renoprival kidneys in lit/lit animals was parallel to that of the control right kidney $(P<0.001)$. The interval between the regression lines was equivalent to a constant difference of approximately $40 \%$ between renoprival and control right kidneys and was similar to that found in the normal heterozygote $(43 \%)$. Increases in DNA, RNA, and protein in control animals during CRG indicate that cell division and hypertrophy were occurring in similar proportions. In the GH-deficient mouse, the total amount of DNA in renoprival kidneys was $0.451 \mathrm{mg}$ compared with $0.439 \mathrm{mg}$ in controls (NS). This suggests that cell replication was suppressed. The protein:DNA ratio increased from 20.91 to $24.27(P<0.001)$ and the RNA:DNA ratio increased from 0.732 to $0.912(P<0.001)$, suggesting that cell size was markedly increased. These findings suggest that reduced amounts of $\mathbf{G H}$ may produce a dissociation between hyperplasia and hypertrophy, with CRG occurring predominantly by cellular hypertrophy.
\end{abstract}

\section{Speculation}

Growth hormone deficiency does not prevent compensatory renal growth, which occurs to the same extent in control and growth-hormone-deficient animals, both of which have undergone nephrectomy. However, the increase in kidney size is accomplished predominantly by cellular hypertrophy instead of cell replication.

Hormones secreted by the anterior pituitary gland influence both normal renal growth $(1,13,14,19,38)$ and compensatory renal growth (CRG) (45). Results of studies on CRG with hypophysectomized animals are inconsistent; some suggest suppression of CRG $(2-5,12,18,34,54,55)$, whereas others report that CRG occurs when body weight (BW) is stabilized $(9,11,15,20$, $21,42,46-48)$. In the Snell dwarf mouse (dw) (51), which has congenital panhypopituitarism, CRG is reported to be normal (6).

We have chosen to investigate the effect of growth hormone (GH) deficiency on CRG. In the hypophysectomized animal, the following results have been reported: $\mathrm{GH}$ replacement only partially restores CRG (3) or has no effect at all $(46,47)$; simultaneous replacement of $\mathrm{GH}, \mathrm{ACTH}$, and thyrotropin causes excessive CRG (42), whereas GH, ACTH, and thyroxine only partially restores CRG (18), and thyroxine alone has no effect (46).

Although $\mathrm{GH}$ is thought to have a primary role in stimulating cell replication (10), the cellular response during CRG after hypophysectomy is in dispute. Mitosis in the renoprival kidney is variously reported to be completely absent $(22,33)$ or merely suppressed $(21,32,49)$. Three days after nephrectomy in hypophysectomized rats, tritiated thymidine shows that mitoses are still $60 \%$ as frequent as normal and GH only partially restores this deficiency (32).

Study of the role of $\mathrm{GH}$ is complicated by the postulated existence of a GH-related "renotrophic factor" (18), for which there is accumulating evidence in vitro $(39,43)$, in vivo $(31)$, and in parabiotic experiments $(29,53)$. Poffenbarger and Prince (42) studied the effect on CRG of nonsuppressible, insulin-like activity because of its similarity to somatomedin (41) (a proposed "second messenger" for GH (24), but nonsuppressible, insulin-like activity actually inhibited CRG in hypophysectomized rats.

Studying the role of $\mathrm{GH}$ is further complicated by problems that hypophysectomy creates in animal models. One of these is the ensuing severity of weight loss. Difficulties due to a relatively greater loss of kidney weight (KW) (42) in hypophysectomized animals, arise when comparing normal animals with those that have lost weight after hypophysectomy. Such problems are overcome by using the allometric relationship between $\mathrm{KW}$ and $\mathrm{BW}$ (25). Another problem is the multiple hormone deficiency. Pituitary ablation may obscure the effect that the hormones exert in combination above and beyond their individual action. To avoid complications due to hypophysectomy, we chose, instead, to use a GH-deficient dwarf mouse strain.

The Little mouse (lit), an ateliotic dwarf strain (16), was used in this study. The animal's autosomal recessive defect appears to be a selective deficiency of pituitary $\mathrm{GH}$, resembling type $1 \mathrm{GH}$ deficiency in humans $(7,16)$. The mice do not have neonatal or pubertal growth spurts, but the females are fertile. They grow with repetitive pregnancies and can achieve normal weights after multiple litters. Although pituitary homogenates are deficient in $\mathrm{GH}$ and prolactin, virgin females are not deficient in circulating prolactin (27). $\mathrm{GH}$ administration or pituitary implantation leads to normal growth (7). Lactation fails after the first pregnancy, suggesting prolactin deficiency; however, lactation after subsequent pregnancies is normal (27). Allometry was used to assess change in KW because of its advantages in comparing animals of different sizes. Estimations of nucleic acids and protein were used to assess the effect of GH deficiency on cell growth.

\section{MATERIALS AND METHODS}

\section{ANIMALS}

Mice used in the experiment were normal heterozygotes (lit/ +) and GH-deficient homozygotes (lit/lit) of the C57BL/6J/lit mouse colony maintained at Royal Children's Hospital, Melbourne, Australia. A small group of mice from the C57BL/6J parent strain $(+/+)$ were also used as controls.

The diet, housing, and details of surgical technique were the same as described in a related paper (25).

Some of the "adolescent" (35-day-old) animals ( $n=6$ in each group) undergoing left nephrectomy or sham operation were monitored for nutritional analysis. BWs and food and water consumption were measured daily. 


\section{EXPERIMENTAL DESIGN}

The growth pattern of lit/lit kidneys relative to BW was determined for both kidneys at 8 to 50 days of age. Left nephrectomy was performed at 5,15 , or 35 days. After a postoperational interval of 15 days, the weight of the right renoprival kidney was determined. Sham nephrectomies were performed at 35 days of age. After a similar 15-day period, KW was determined. All subgroups had equal numbers of male and females. Both lit/ $+(25)$ and $+/$ + controls had either nephrectomy or sham operation 15 days before weight determinations.

\section{PROTEIN AND NUCLEIC ACID ANALYSIS}

Adolescent female mice from lit/lit, lit/+ and +/+ groups were used to assess changes in DNA, RNA, and protein after nephrectomy or sham operation. All kidneys were immediately stored at $-20^{\circ} \mathrm{C}$ after determination of the wet weight and subsequently analyzed in batches. Whole kidneys were homogenized in water for $20 \mathrm{sec}$ at setting 5 of a Polytron PCU-2 homogenizer (56). The volume was adjusted to give a final concentration of about $10 \mathrm{mg}$ of tissue per ml. Separate aliquots of the homogenate were used for quantitating nucleic acids and protein. DNA concentration was determined by the fluorometric technique of Kissane and Robins (28). RNA was extracted from the tissue according to the Munro and Fleck (37) modification of the Schmidt-Thannhauser procedure. The ribose content of the extract was obtained by a modified Bial orcinol reation for pentoses (30). Protein concentration was determined by a modification of the Lowry method using bovine serum albumin as the standard (40). The total amount of DNA, RNA, and protein in each kidney was determined from their respective concentration and $\mathrm{KW}$. The protein:DNA and the RNA:DNA ratios were determined from the total amounts. The protein:DNA ratio reflects the amount of cytoplasm in each cell and is hence an estimate of cell size, presuming a constant water content of the kidney. Kidneys from lit/lit and lit/+ animals were dried to determined the ratio of dry $\mathrm{KW}$ (DKW):wet $\mathrm{KW}$. The RNA:DNA ratio represents the number of ribosomes in the cell and provides an indirect estimate of cell size.

\section{DATA ANALYSIS}

The data were transformed to logarithms to minimize differences among animal age and size. Linear regression analysis was then used to determine the allometric relationship between $\mathrm{KW}$ and BW. Regression equations were calculated by the method of least squares with an Olivetti P602 minicomputer. Analysis of covariance with a sequential $F$ test was used to compare the different groups (36). The degree of CRG was determined by measurement of the vertical interval between the regression lines for renoprival and control groups. The logarithmic interval, equivalent to a ratio between the (logarithmic) means of renoprival and control KWs was then expressed as the percentage difference between the renoprival and control KWs. Protein and nucleic acid estimations were expressed as mean \pm S.D. and compared by $t$ test.

\section{RESULTS}

The BWs of adolescent lit/lit and lit/+ mice were recorded daily from day 35 and are shown in Figure 1. The lit/lit mice did not have pubertal growth spurts. The mean BW remained in the range of 8 to $10 \mathrm{~g}$. Operation interrupted somatic growth in lit/+ mice for 1 to 2 days and for a slightly longer period in the lit/lit mice. The daily specific growth rate $\left({ }^{\mathrm{B} W} / \mathrm{Bw}\right)$ between renoprival and sham groups was not significantly different for either lit/lit or lit/+ animals. The total input of water over 15 days was not significantly different between nephrectomized and sham operated groups in both lit/lit and lit/+ animals. Similarly, the chow consumed per $100 \mathrm{~g} \mathrm{BW}$ each day was not significantly different between lit/lit and lit/+ mice.

Normal renal growth in lit/lit animals from 8 to 50 days of age was determined by linear regression analysis for right $\mathrm{KW}$ (86 animals) and total $\mathrm{KW}$ (58 animals) (Fig. 2). The correlation coefficient (r), regression slope (b), intercept (a), S.E. (slope), and S.E. (estimate) for control and renoprival kidneys are shown in Table 1. No differences between males and females were found for right $\mathrm{KW}$ or for total $\mathrm{KW}$. The regression slopes were 0.93 and 0.94 , respectively (NS). The right KWs of the sham group (both sexes) and controls (both sexes) were not significantly different, hence the kidneys after sham operation are shown together with the control right kidney in Figure 2. There was no sex difference for the lit/lit renoprival kidney, permitting calculation of a common regression equation (Fig. 3). The regression slope was 0.84 and was parallel to the control right kidney $(P<0.001)$. The interval between the regression lines was equivalent to a constant difference of approximately $40 \%$ between renoprival and control right kidneys.

DKW was determined for both lit/lit and lit/+ animals aged between 20 and 50 days (Table 2). The percent DKW at 35 days or 50 days (after nephrectomy or sham operation) was not significantly different, although the percent $D K W$ was consistently lower in the 20 - and 30 -day-old animals than at 50 days $(P<0.02)$ for both lit/lit and lit/+ mice.

In the control lit/ + and $+/+$ mice, the concentrations of kidney DNA, RNA, and protein were not significantly affected by CRG, although there were significant rises in the total amounts (Table 3). The ratios of protein:DNA and RNA:DNA, which reflect the

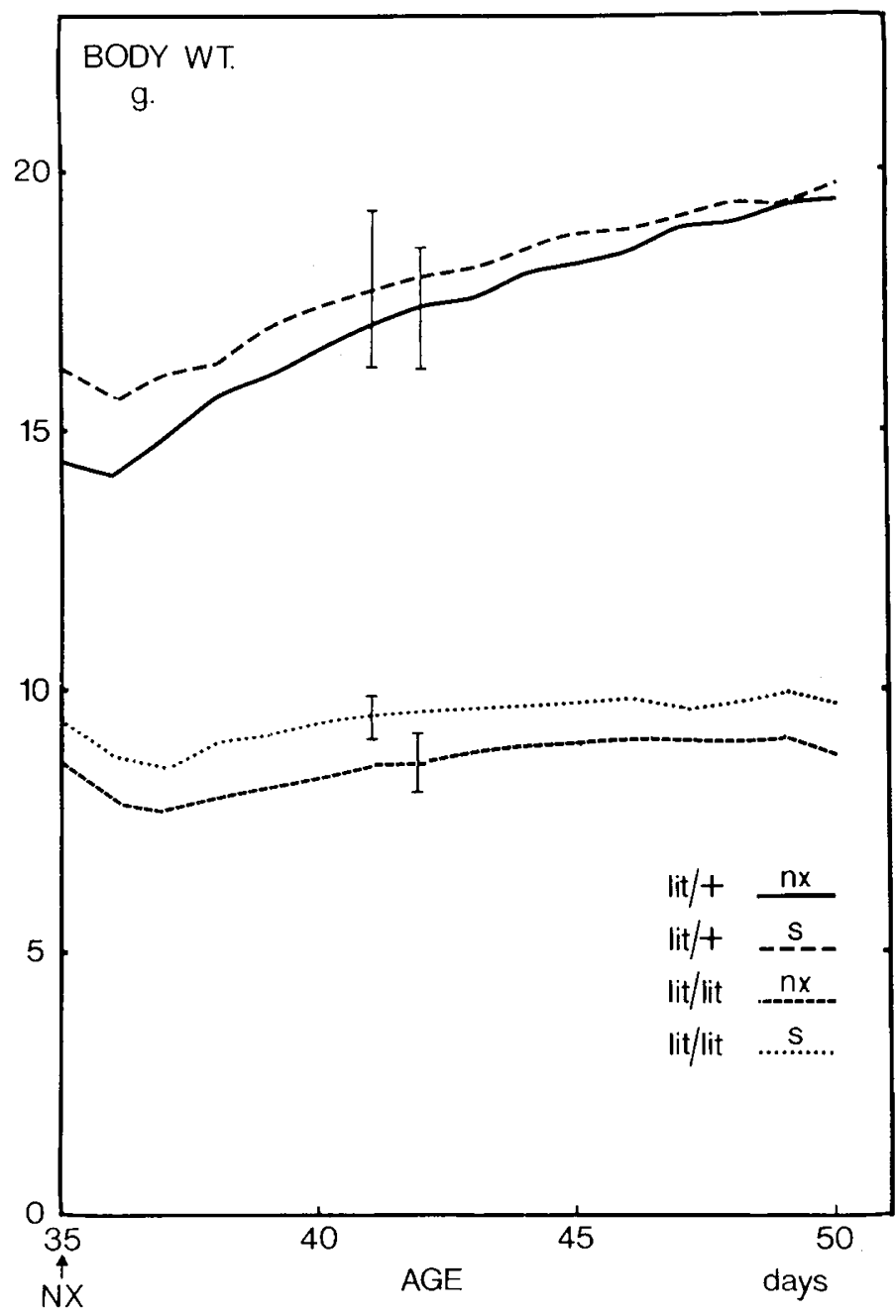

Fig. 1. BW growth curves of lit/lit and lit/+ mice after nephrectomy $(N x)$ or sham operation (S). Points, mean body weight for six animals. The standard deviation was almost constant in each group throughout and is only shown once. 


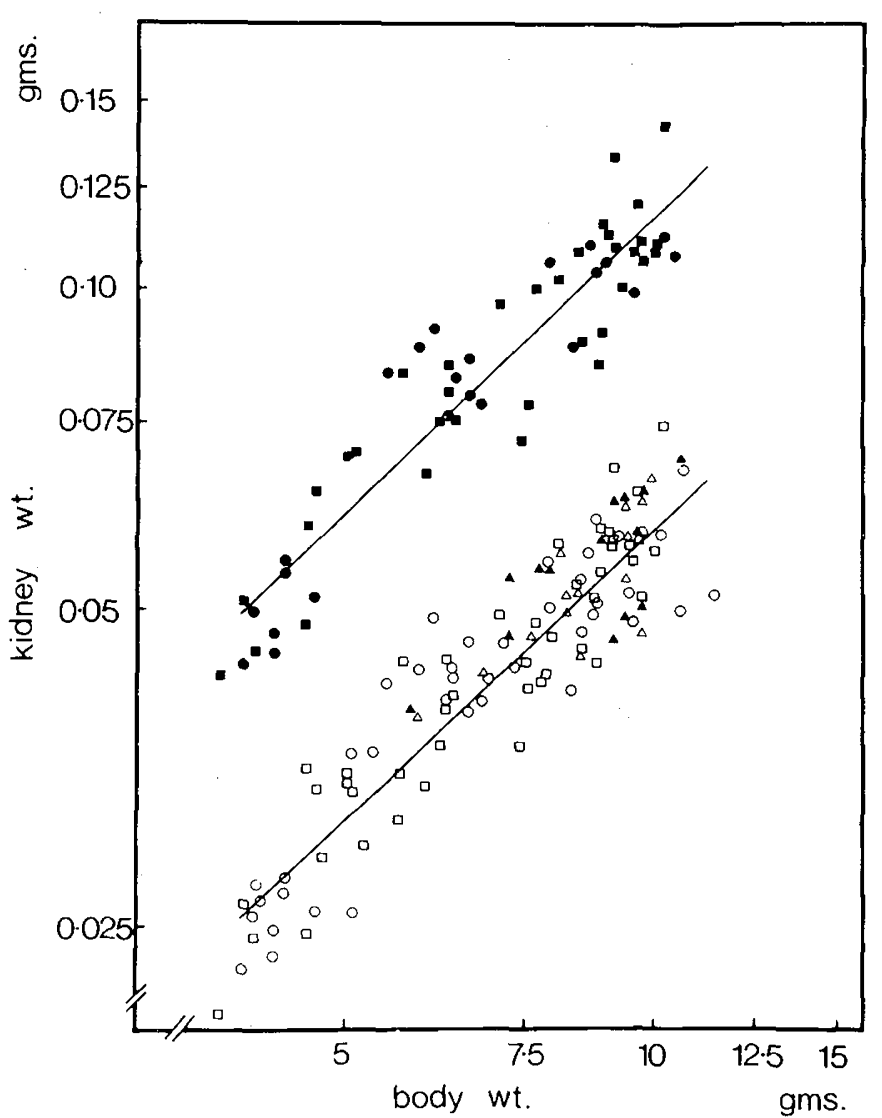

Fig. 2. Regressions for normal $\mathrm{KW}$ versus $\mathrm{BW}$ - in lit/lit mice. The upper line is for total KW [males ( $\boldsymbol{\square})$; females $(\boldsymbol{\bullet})$ ], and the regression equation is $\mathrm{KW}=0.0134 \mathrm{BW}^{0.94}(r=0.932)$. The lower line is for the right $\mathrm{KW}$ [males $(\square)$; females $(O)$ ], the regression equation being $\mathrm{KW}=0.0056$ $\mathrm{BW}^{0.93}(\mathrm{r}=0.922)$. The sham nephrectomies [males $(\boldsymbol{\Delta})$; females $(\Delta)$ ] are shown with the control right kidney.

There is no significant difference between males and females for right $\mathrm{KW}$ $[F(2,82)=0.411$, N.S.] or for total $\mathrm{KW}[F(2,54)=0.278$, N.S.]. The slopes of the regressions for right $\mathrm{KW}$ and total $\mathrm{KW}$ are the same $[F(2$, $140)=577 ; P<0.001$ for population difference; $F(1,140)=0.069$, N.S. slope difference; $F(1,140)=1154 ; P<0.001$ for parallelism]. There is also no significant difference between the control right $\mathrm{KW}$ and the right $\mathrm{KW}$ after sham nephrectomy $[F(2,110)=2.046$, N.S. $]$.

Table 1. Parameters for regression lines of $K W$ versus $B W$ calculated after logarithmic transformtion of the data obtained from the lit/lit mouse.

\begin{tabular}{|c|c|c|c|c|}
\hline & $\begin{array}{c}\text { No. of } \\
\text { animals }\end{array}$ & Slope & $\begin{array}{c}\text { Intercept } \\
\text { (esti- } \\
\text { mated) }\end{array}$ & $\mathrm{r}$ \\
\hline \multicolumn{5}{|c|}{ Controls (both sexes) } \\
\hline Total KW & 58 & $\begin{array}{c}0.943 \\
\pm 0.049^{1}\end{array}$ & $\begin{array}{l}-1.871 \\
\pm 0.041\end{array}$ & 0.932 \\
\hline Right KW & 86 & $\begin{array}{r}0.926 \\
\pm 0.042\end{array}$ & $\begin{array}{l}-2.248 \\
\pm 0.036\end{array}$ & 0.922 \\
\hline \multicolumn{5}{|c|}{$\mathrm{Nx}^{2}$ (both sexes) } \\
\hline Right $\mathrm{KW}$ & 53 & $\begin{array}{r}0.840 \\
\pm 0.092\end{array}$ & $\begin{array}{l}-1.928 \\
\pm 0.083\end{array}$ & 0.787 \\
\hline
\end{tabular}

\footnotetext{
${ }^{1}$ Mean \pm S.E.

${ }^{2} \mathrm{Nx}$, Nephrectomy (left).
}

amount of protein and ribosomes respectively in each cell, were only marginally elevated (Fig. 4).

Inasmuch as RNA and protein concentrations were not affected, the DNA concentration in the GH-deficient mouse was statistically lower after CRG $(P<0.001)$. There was a significant increase

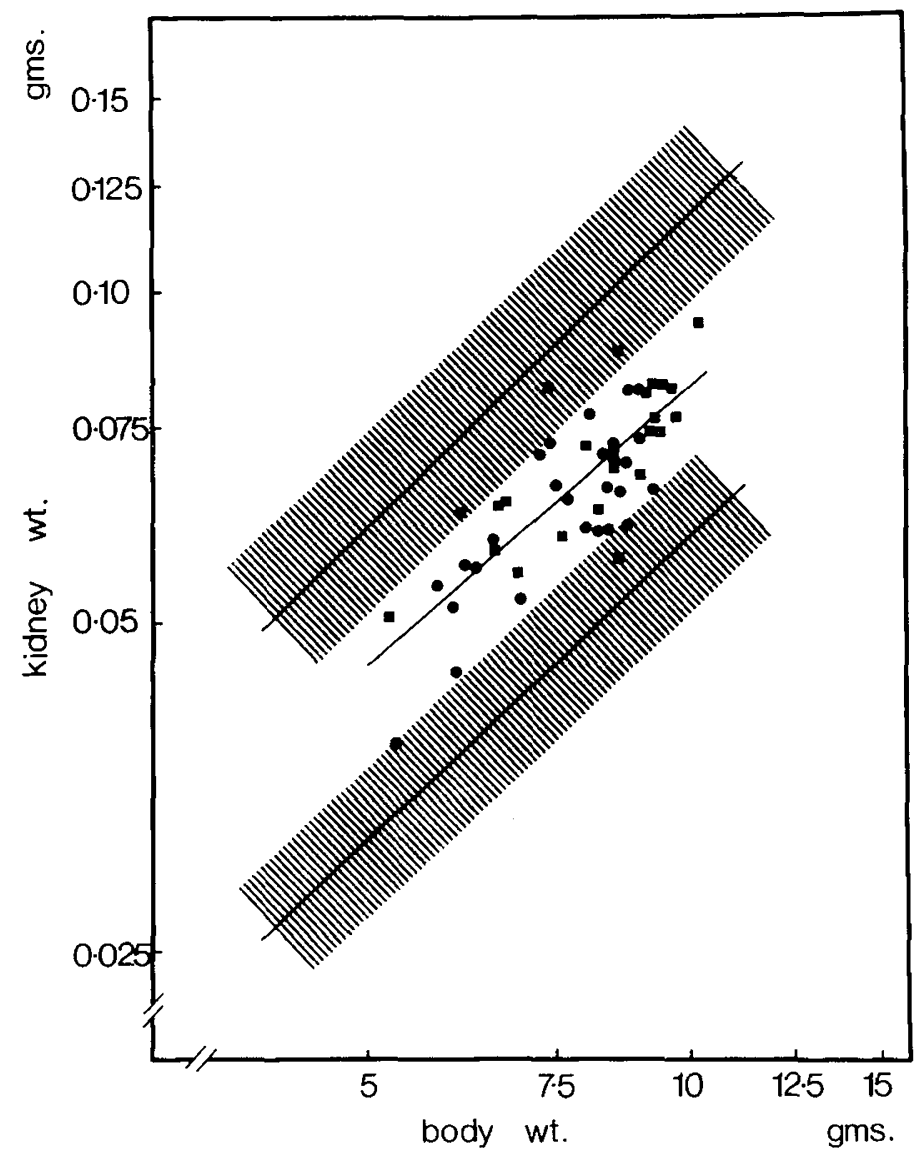

Fig. 3. Regression for the renoprival kidney in lit/lit mice [males ( $\square$ ); females (@)]. There is no significant difference between the sexes $[F(2,49)$ $=1.046$, N.S.]. The regression equation for the renoprival kidney is $\mathrm{KW}$ $=0.0118 \mathrm{BW}^{0.84}(\mathrm{r}=0.787)$. The regression lines for the controls (right $\mathrm{KW}$ and total $\mathrm{KW}$ ) are shown with the cross-hatched areas representing \pm 2 S.D., such that about $95 \%$ of the control data would lie within these areas. The renoprival and right control $\mathrm{KW}$ regressions are parallel $[F(2$, $135)=131 ; P<0.001$ for population difference; $F(1,135)=0.658$, N.S. slope difference; $F(1,135)=262 ; P<0.001$ for parallelism]. The interval between the regressions is equivalent to a constant difference of approximately $40 \%$ between renoprival and control right kidneys.

in total RNA and protein $(P<0.005)$, suggesting very active growth of cellular mass. By contrast, the total amount of DNA was unchanged which suggests suppression of cell replication. The protein:DNA and RNA:DNA ratios were both significantly elevated $(P<0.001)$, supporting the conclusion that cell size was markedly increased. These results suggest that with GH deficiency, CRG was occurring predominantly by cell hypertrophy.

\section{DISCUSSION}

The Little mouse is a more reliable model for study of GH deficiency than the hypophysectomized rat or the Snell dwarf (dw) mouse because the young virgin animal does not have multiple hormone deficiencies. Nutrition is monitored during CRG because a high protein diet or restricted food and water intake distort the results $(44,50)$. Unlike the hypophysectomized rat or the dw mouse, the lit/lit mouse has a normal food intake after operation.

The allometric relationships for the right kidney and for the total renal mass in the lit/lit mouse are very similar to those of the heterozygote control (25). The slope of the right $\mathrm{KW}$ regression is slightly greater in the lit/lit $(0.93)$ than in the lit/+ $(\simeq 0.86)$, but the general form is the same. Although extensive data are not available for the $+/+$ control, there is substantiating evidence 
from the small numbers in this study that renal growth is the same in both lit $/+$ and $+/+$ controls. The growth of the renoprival kidney in the lit/lit animal is similar to that in the normal mouse. The renoprival kidney is $40 \%$ heavier than controls, compared with $43 \%$ in the lit/ + mouse (25). This suggests that the mechanism

Table 2. Dry $K W$ as a percentage of wet $K W$ after nephrectomy or sham operation in lit/ + and lit/lit mice

\begin{tabular}{|c|c|c|c|c|}
\hline & \multicolumn{4}{|c|}{ Age (days) } \\
\hline & $5-20$ & $15-30$ & 35 & $35-50$ \\
\hline \multicolumn{5}{|l|}{$\mathrm{Lit} /+$} \\
\hline Control & & & $\begin{array}{l}23.7 \\
\pm 0.8^{1}(10)^{2,3}\end{array}$ & \\
\hline $\mathrm{Nx}^{4}$ & $\begin{array}{l}22.5 \\
\pm 1.3(7)^{5}\end{array}$ & $\begin{array}{l}24.3 \\
\pm 0.6(7)\end{array}$ & & $\begin{array}{r}24.3 \\
\pm 1.2\end{array}$ \\
\hline $\mathrm{S}^{6}$ & $\begin{array}{l}22.9 \\
\pm 0.8(6)\end{array}$ & $\begin{array}{l}24.7 \\
\pm 1.2(7)\end{array}$ & & $\begin{array}{l}23.8 \\
\pm 1.2\end{array}$ \\
\hline \multicolumn{5}{|l|}{ lit/lit } \\
\hline Control & & & $\begin{array}{r}24.3 \\
\pm 1.8 \quad(6)^{3}\end{array}$ & \\
\hline $\mathrm{Nx}$ & $\begin{array}{l}22.9 \\
\pm 1.2(6)\end{array}$ & $\begin{array}{l}22.3 \\
\pm 2.3(8)\end{array}$ & & $\begin{array}{l}24.8 \\
\pm 1.4(14)\end{array}$ \\
\hline$S$ & & & & $\begin{array}{l}24.8 \\
\pm 1.3\end{array}$ \\
\hline
\end{tabular}

\footnotetext{
${ }^{1}$ Mean \pm S.D.

${ }^{2}$ Numbers in parentheses, number of kidneys.

${ }^{3}$ Values are for the left kidney only.

${ }^{4}$ Nephrectomy (left).

${ }^{5}$ Values for the renoprival (right) kidney.

${ }^{6}$ Sham left nephrectomy.
}

controlling renal size is not affected by GH deficiency which is responsible for the smaller dimensions of the lit/lit mouse.

To estimate the number of cells, one assumes that the total DNA content of the kidney represents a distribution of nuclear DNA that is constant (8). Binucleate and polyploid cells are reported in CRG (52), but the mean diploid DNA content remains unchanged or is minimally elevated (17). Therefore, an increase in DNA content is a reasonable indicator of cell replication. The protein:DNA ratio represents the amount of cytoplasm in each cell and is, therefore, a measure of cell size. The constant ratio of DKW:wet KW found in each group supports the assumption that CRG does not significantly alter the renal water content and, therefore, permits the valid use of this "size" ratio. The RNA: DNA ratio represents the number of ribosomes in each cell, and hence provides an indirect measure of cell size.

In renoprival kidneys of normal mice, increases in total DNA, RNA, and protein represent a combination of cellular hyperplasia and hypertrophy which occurs in CRG (26). Our values for DNA and RNA concentrations are slightly greater than those reported by others for 42-day-old mice 15 days after nephrectomy (35). Similarly, the increase in RNA:DNA ratio is not as dramatic as that in older mice (35). This reflects little increase in cellular polyribosomes. The protein:DNA ratio is only marginally elevated, suggesting that between 35 and 50 days of age CRG occurs by both hyperplasia and hypertrophy in similar proportions.

In the lit/lit renoprival kidney, the lack of DNA accumulation but increase in protein:DNA ratio suggests that $C R G$ may be due to cellular hypertrophy. The total protein and the RNA:DNA ratio are significantly elevated, supporting the view that protein accretion and the number of ribosomes in each cell are greater than in controls. Suppression of DNA accumulation and, therefore, cell replication in the GH-deficient animal suggests that $\mathrm{GH}$ may be essential for cell division. Similar results have been found in a study of muscle in lit/lit mice (23). Cheek and Graystone (10) propose that GH acts primarily to stimulate cell division. The

Table 3. Changes in whole kidney composition after nephrectomy or sham operation in females

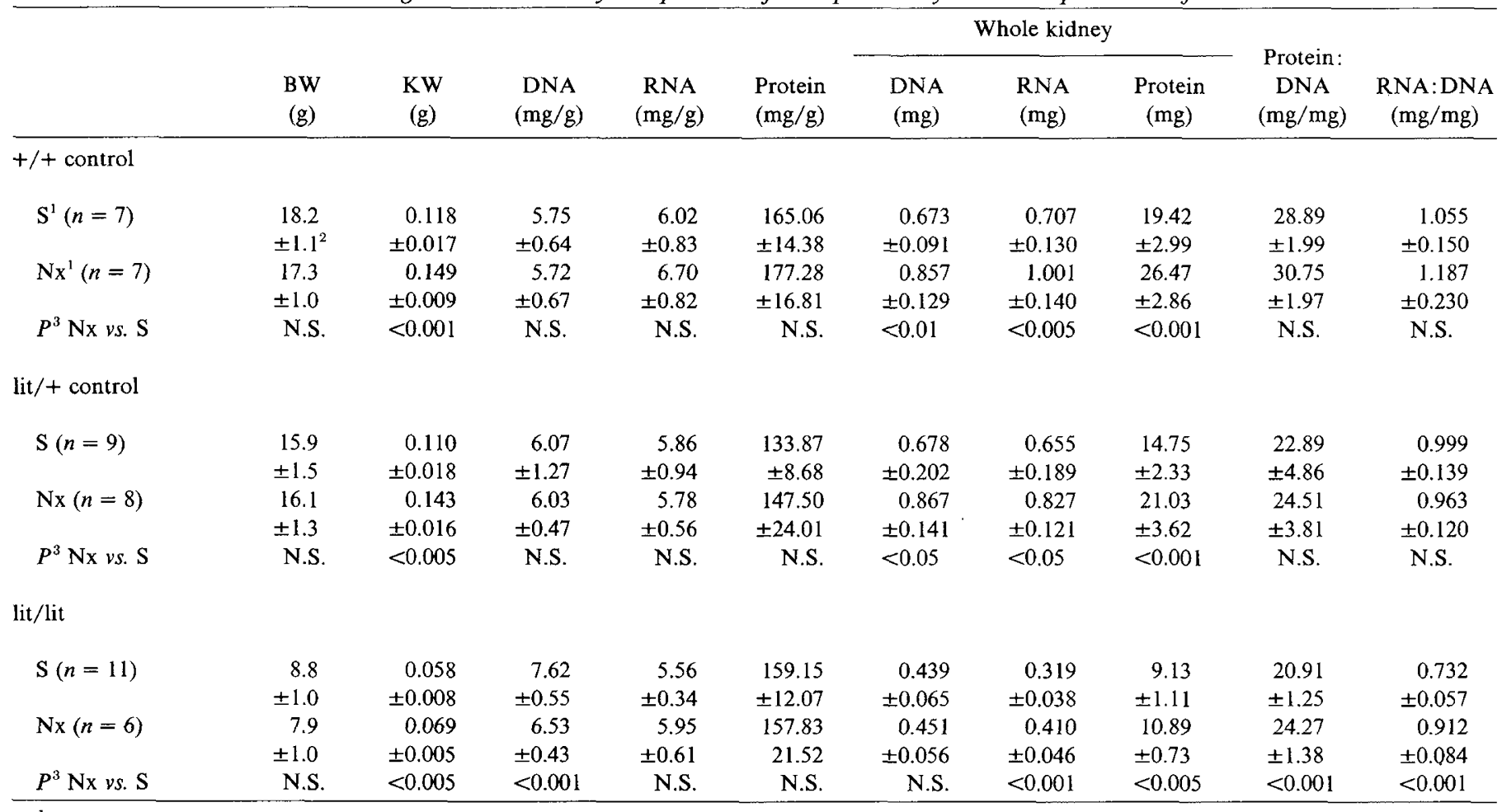

\footnotetext{
'S, sham nephrectomy; Nx, nephrectomy, NS, nonsignificant.

${ }^{2}$ Mean \pm S.D.

${ }^{3}$ Comparison by $t$ test of kidney after nephrectomy or sham operation. Nonsignificant (NS) indicates values of $P>0.05$.
} 

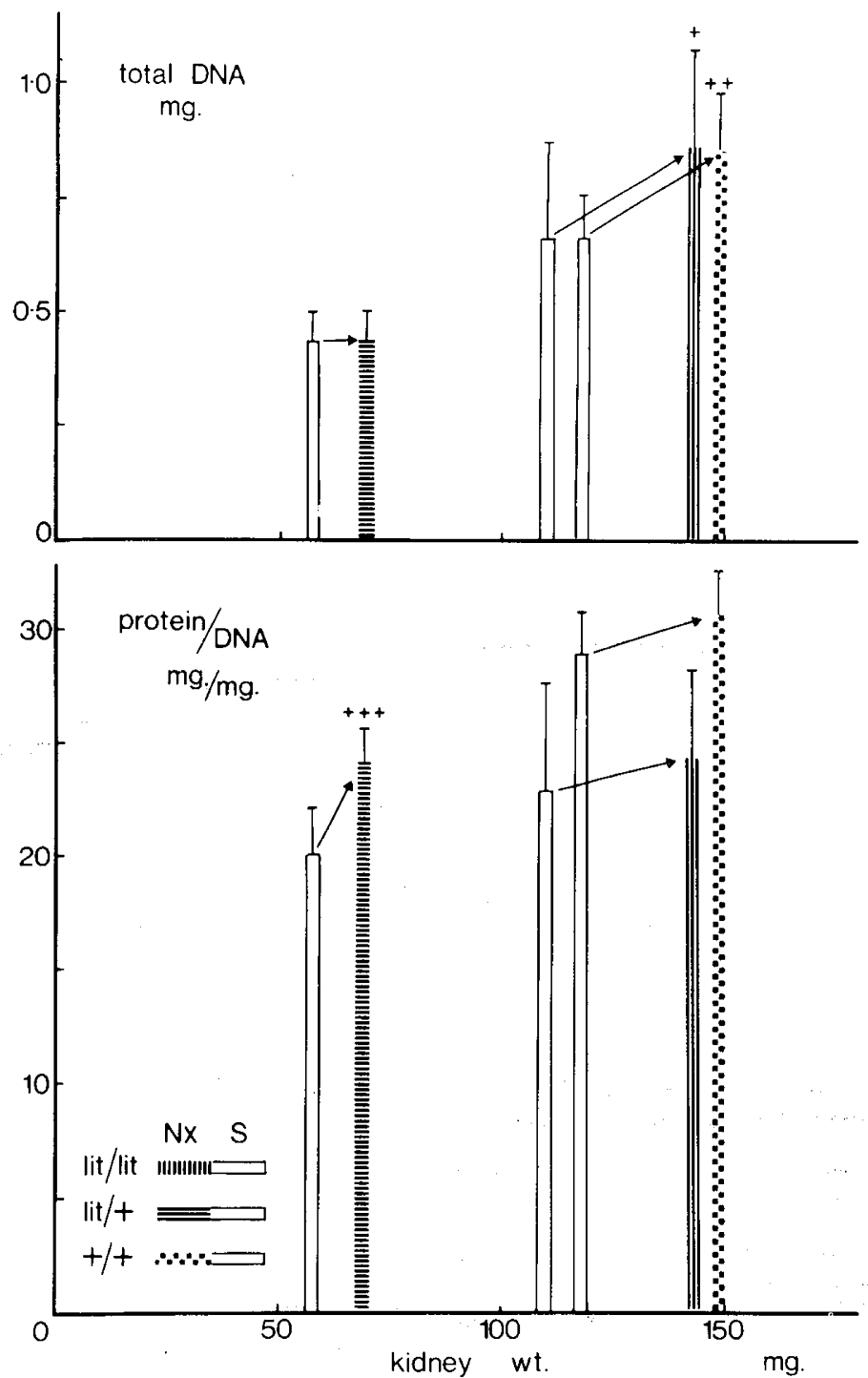

Fig. 4. Changes in total DNA and protein:DNA ratio in the kidneys of lit/lit, lit/ + , and $+/+$ mice after nephrectomy $(N x)$ or sham operation (S). The histograms represent the mean \pm S.D. for six to 11 animals plotted against $\mathrm{KW}$. The total DNA is significantly elevated in the renoprival kidney of lit $/+(P<0.05)$ and.++ mice $(P<0.01)$, consistent with cell replication occurring. The protein:DNA ratios are not significantly changed, suggesting coincidental cellular hypertrophy. In the lit/lit mice, total kidney DNA remains essentially constant, wheres the protein:DNA ratio is significantly elevated $(P<0.001)$, consistent with growth occurring predominantly by cellular hypertrophy.,$+ P<0.05$;,$++ P<0.01$; ,$+++ P<0.001$.

results presented here support such a proposed role for $\mathrm{GH}$ in the kidney.

The apparent inconsistency between normal CRG (as measured by $\mathrm{KW}$ ) and the reported suppression of cell division in hypophysectomized animals can now be explained in the light of the present results. Although the amount of CRG is relatively normal in the GH-deficient mouse, cell division may be suppressed. Lack of $\mathrm{GH}$ appears to produce dissociation between hyperplasia and hypertrophy with CRG occurring predominantly by cellular hypertrophy.

\section{REFERENCES AND NOTES}

1. Astarabadi, T.: Failure of purified growth hormone to restore the size of the kidneys in hypophysectomized rats. Nature (Lond.), 192: 270 (1961),
2. Astarabadi, T.: The regression in size of the hypertrophic remaining kidney after hypophysectomy in rats. Q. J. Exp. Physiol., 47: 93 (1962)

3. Astarabadi, T.: The effect of hypophysectomy, adrenalectomy and ACTH administration on compensatory renal hypertrophy in rats. Q. J. Exp. Physiol., 48: $80(1963)$.

4. Astarabadi, T.: The effect of growth and lactogenic hormones on renal compensatory hypertrophy in hypophysectomized rats. Q. J. Exp. Physiol., 48: 85 (1963).

5. Astarabadi, T.: and Essex, H. E.: The effect of hypophysectomy on compensatory renal hypertrophy after unilateral nephrectomy. Am. J. Physiol., 173: 526 (1953).

6. Basinger, G. T., and Gittes, R. F.: Compensatory renal hypertrophy in male dwarf mice. Invest. Urol., 13: 165 (1975).

7. Beamer, W. G., and Eicher, E. M.: Stimulation of growth in the Little mouse. J. Endocrinol. 71:37 (1976).

8. Boivin, A., Vendreley, R., and Vendreley, D.: L'acid deoxyribonucleique due noyau cellulaire depositaire des carateres hereditaires: arguments d'ordre analytique. Compt. Rend. Acad. Sci., 226: 1061 (1948).

9. Braun-Menendez, E., and Houssay, H. E. J.: Hypertrophie compensatrice due rein chez la rate hypophysectomisee. Compt. Rend. Soc. Biol., 143: 1255 (1949)

10. Cheek, D. B., and Graystone, J. E.: Insulin and growth hormone: regulators of growth with particular reference to muscle. Kidney Int., 14: 317 (1978).

11. Collip, J. B.: Results of recent studies on anterior pituitary hormones. Edin. Med. J., 45: 782 (1938).

12. Colonge, R.: Action de l'hypophyse sur l'hypertrophie renale compensatrice. Compt. Rend. Soc. Biol., I38: 494 (1944).

13. Cushing, H., and Davidoff, L. M.: The pathological findings in four autopsied cases of acromegaly with a discussion of their significance. Monograph 22 (Rockefeller Inst. Mod. Res., New York, 1927)

14. Dandy, W. E., and Reichert, F. L.: Studies on experimental hypophysectomy in dogs. III Somatic, mental and glandular effects. Bull. J. Hopkins Hosp., 62: $122(1938)$.

15. Dicker, S. E., Greenbaum, A. L., and Morris, C. A.: Compensatory renal hypertrophy in hypophysectomized rats. J. Physiol. (Lond.), 273: 241 (1977).

16. Eicher, E. M., and Beamer, W. G.: Inherited ateliotic dwarfism in mice. J. Hered., 67: 87 (1976).

17. Fautrez, J., Cavalli, G., and Pisi, E.: Variation in the amounts of deoxyribonucleic acid in the celi nuclei and its correlation with mitotic activity: compensatory hypertrophy of the kidney. Nature (Lond.), 175: 684 (1955).

18. Fogelman, A., and Goldman, R.: Effects of hypophysectomy and growth hormone on renal compensatory hypertrophy in rats. Proc. Soc. Exp. Biol. Med. 122: 568 (1966).

19. Fontaine, T.: Sur le mecanisme de la regression renale a la suite de l'hypophysectomie chez le rat. Arch. Sci. Physiol., 1: 357 (1948).

20. Fontaine, T., and Veil, C.: Hypertrophie renale compensatrice chez le rate hypophysoprive. Compt. Rend. Soc. Biol., 140: 159 (1946).

21. Fontaine, T., and Veil, C.: Hypertrophie renale compensatrice chez le rat hypophysoprive. Arch. Sci. Physiol., 1: 49 (1947).

22. Goss, R. J., and Rankin, M.: Physiological factors affecting compensatory renal hyperplasia in the rat. J. Exp. Zool., 145: 209 (1960).

23. Graystone, J. E.: Determination of DNA-unit size and number of skeletal muscle during post-natal development and following growth hormone treatment in the little mouse. J. Endocrinol., (in press).

24. Hall, K., and Van Wyk, J. J. L.: Somatomedin Curr. Top. Exp. Endocrinol., 2: 155 (1974).

25. Hutson, J. M., Holt, A. B., Egami, K., Niall, M., Fowler, R., and Cheek, D. B. Compensatory renal growth in the mouse. I. Allometric approach to the effect of age. Pediatr. Res., 15: 0000 (1981)

26. Karp, R., Brasel, J. H., and Winick, M.: Compensatory kidney growth after uninephrectomy in adult and infant rats. Am. J. Dis. Child., I2I: 186 (1971).

27. Keough, E. M., and Wood, B. G.: Mammary gland development during pregnancy in the dwarf mouse mutant, Little. Tissue Cell, 11: 773 (1979).

28. Kissane, J. M., and Robins, E.: The fluorometric measurement of deoxyribonucleic acid in animal tissues with special reference to the central nervous system. J. Biol. Chem., 233: 184 (1958).

29. Kurnick, N. B., and Lindsay, P. A.: Compensatory renal hypertrophy in parabiotic mice. Lab. Invest., 19: 45 (1968).

30. Lin, R. I., and Schjlide, O. H.: Micro estimation of RNA by the cupric ion catalyzed orcinol reaction. Anal. Biochem., 27: 473: (1969).

31. Lowenstein, L. M., and Stern, A.: Serum factor in renal compensatory hyperplasia. Science (Wash. D. C.), 142: 1479 (1963).

32. McCreight, C. E., and Reiter, R. J.: Effects of hormones on the renal response to unilateral nephrectomy in hypophysectomized rats. J. Exp. Zool., 166: 65 (1967).

33. McCreight, C. E., and Sulkin, N. M.: Effects of unilateral nephrectomy in hypophysectomized rats. Anat. Rec., 142: 256 (1962).

34. McQueen-Williams, M., and Thompson, K. W.: The effect of ablation of the hypophysis upon the weight of the kidney of the rat. Yale J. Biol. Med., 12: 531 (1940).

35. Malt, R. A., and Lemaitre, D. A.: Accretion and turnover of RNA in the renoprival kidney. Am. J. Physiol., 214: 1041 (1968).

36. Mellits, D. E.: Statistical methods. In: D. B. Cheek: Human growth. Body composition, cull growth, energy and intelligence. Chap. 2 (Lea and Febiger, Philadelphia, 1968).

37. Munro, H. N., and Fleck, A.: Recent developments in the measurements of nucleic acids in biological materials. Analyst, 91: 78 (1966). 
38. Nicholson, W. E., Barton, R. N., Puett, D., Orth, D. N., and Liddle, G. W.: Evidence for renotropic activity in ovine pituitaries. Endocrinology, 105: 16 (1979).

39. Ogawa, K., and Nowinski, W. W.: Mitosis stimulating factor in serum of unilaterally nephrectomized rats. Proc. Soc. Exp. Biol., Med., 99: 350 (1958).

40. Peterson, G. L.: A simplification of the protein assay method of Lowry et al which is more generally acceptable. Anal. Biochem., 83: 346 (1977).

41. Poffenbarger, P. L.: Purification and partial characterization of human serum nonsuppressible insulin-like activity (NSILA) J Clin. Invest, 56: 1455 (1975).

42. Poffenbarger, P. L., and Prince, M. J.: The role of serum nonsuppressible insulinlike activity (NSILA) in compensatory renal growth. Growth, 40: 83 (1976).

43. Preuss, H. G., and Goldin, H.: Humoral regulation of compensatory renal growth Med. Clin. N. Am., 59: 771 (1975).

44. Reiter, R. J.: Cellular proliferation and deoxyribonucleic acid synthesis in compensatory kidneys of mice and the effect of food and water restriction. Lab. Invest., 14: 1636 (1965)

45. Reiter, R. J.: The endocrines and compensatory renal enlargement. In: W. W. Nowinski, and R. J. Goss: Compensatory Renal Hypertrophy. pp. 183-204. (Academic Press, Inc., New York, 1969).

46. Rolf, D., and White, H. L.: Endocrine influences on renal compensatory hypertrophy. Endocrinology, 53: 436 (1953).

47. Ross, J., and Goldman, J. K.: Compensatory renal hypertrophy in hypophysectomized rats. Endocrinology, 87: 620 (1970).

48. Selye, H., Mortimer, H., Thompson, D. L., and Collip, J. B.: Effect of parathyroid extract on the bones of the hypophysectomized rat. A histologic study. Arch. Pathol., 18: 878 (1934).

49. Simpson, D. P.: Hyperplasia after unilateral nephrectomy and role of excretory load in its production. Am. J. Physiol., 201: 517 (1961).

50. Smith, A. H., and Moise, T. S.: Diet and tissue growth. IV. The rate of compensatory renal enlargement after unilateral nephrectomy in the white rat. J. Exp. Med., 45: 263 (1927)

51. Snell, G. D.: Dwarf, a new mendelian recessive character of the house mouse. Proc. Natl. Acad. Sci. U. S. A., 15: 733 (1929).

52. Sulkin, N. M.: Cytologic studies of the remaining kidney following unilateral nephrectomy in the rat. Anat. Rec., 105: 95 (1949).

53. Van Vroonhoven, T. J., Soler-Montesinos, L., and Malt, R. A.: Humoral regulation of renal mass. Surgery, 72: 300 (1972).

54. White, H. L., Heinbecker, P., and Rolf, D.: Effects of hypophysectomy on some renal functions. Proc. Soc. Exp. Biol. Med., 46: 44 (1941).

55. Winternitz, M. C., and Waters, L. L.: The effect of hypophysectomy on compensatory renal hypertrophy in dogs. Yale J. Biol. Med., 12: 705 (1940).

56. Kinematica, Luzern, Switzerland.

57. The authors thank Maggie Niall for help with the preliminary work, Donald Evans for technical assistance, and Cheryl Robinson for typing the manuscript. The help of Brenda LeGrand and Howard Fiedler with the biochemistry is gratefully appreciated.

58. Requests for reprints should be addressed to: Dr. John M. Hutson, c/o Department of Pediatric Surgery, Massachusetts General Hospital, Fruit St., Boston, MA 02114 (USA).

59. This research was supported in part by grants from the Australian Kidney Foundation and Felton Request.

60. Received for publication July 15, 1980

61. Accepted for publication February 1, 1981. 